\title{
Procesos y formas de producción campesina en el norte del Departamento del Cauca: agricultores del cacao en Puerto Tejada, $1920-1936^{1}$
}

Doi: $10.25100 /$ hye.v14i50.6489

Artículo recibido: 03-03-2017 | Artículo aceptado: 11-10-2017

\section{César Enrique Zape Jordán}

Historiador de la Universidad del Valle (Cali, Colombia). Miembro del semillero de investigación Modernidad y modernización en el Valle del Cauca, siglos XIX-XXI, adscrito al grupo CUNUNO, a la vez perteneciente al Departamento de Historia (Facultad de Humanidades) de la Universidad del Valle. Investigador de los procesos sociohistóricos de las comunidades del norte del Cauca desde la Historia económica y cultural, en especial de la economía campesina de Puerto Tejada a inicios del siglo XX. Correo electrónico: cesar.zape@ correounivalle.edu.co.

Forma de citar este artículo: Zape Jordán, César Enrique. "Procesos y formas de producción campesina en el norte del Departamento del Cauca: agricultores del cacao en Puerto Tejada, 19201936". Historia y Espacio, vol. 14, nº 50 (2018): 15-52. Doi: 10.25100/hye.v14i50.6489.

1 Esta investigación hace parte de un proyecto individual más grande denominado Producción agrícola en el norte del Cauca: agricultores del cacao en Puerto Tejada, 1916-1934, el cual tuvo como objetivo fundamental dar cuenta de los procesos y formas campesinas de producción del cacao en Puerto Tejada en el contexto del proyecto de modernización nacional a inicios del siglo XX. Artículo de investigación. 


\section{Procesos y formas de producción campesina en el norte del Departamento del Cauca: agricultores del cacao en Puerto Tejada, 1920-1936}

Resumen: El objetivo de este artículo es explicar el proceso productivo del cacao en la subregión del norte del Cauca (tomando como referencia el caso de Puerto Tejada) entre 1920 y 1936 a partir de los sujetos involucrados. Tendré en cuenta para dicho fin tanto la variable económica como el papel jugado por los principios éticos, las instituciones comunitario-familiares y la conformación del territorio, en el contexto de la configuración capitalista en la región. La investigación supuso un ejercicio de reconstrucción histórica, el cual partió del análisis cualitativo producto de la triangulación de diferentes tipos de fuentes recogidas en varias unidades documentales del país, y de revisar colecciones documentales personales de algunos habitantes de Puerto Tejada, lugar en el que también hallé la totalidad de las fuentes orales.

Palabras clave: historia de la producción agrícola, economía campesina, agricultor nortecaucano, producción de cacao, modernización.

\section{Processes and forms of peasant production in the north of Cauca Department: cocoa agricultors in Puerto Tejada, 1920-1936}

Abstract: The purpose of this paper is to explain the productive process of cocoa in the north Cauca subregion (choosing as model the Puerto Tejada case) between 1920 and 1936 from the perspective of the involved actors. I will consider aspects such as the economic variable, the role of ethical principles, the community and familiar institutions and the territorial conformation, in the context of the capitalist configuration in the region. The research had a historical reconstruction process that stated from the qualitative analysis of different types of documents, which it was collected in several documentary units in Colombia, and I also checked individual documental collections from some Puerto Tejada's native people. Right There, I found all oral documents I used in this paper.

Keywords: history of the farming production, peasant economy, agricultor of the north of Cauca, cocoa production, modernization process. 


\section{Procesos y formas de producción campesina en el norte del Departamento del Cauca: agricultores del cacao en Puerto Tejada, 1920-1936}

\section{Introducción}

Puerto Tejada es una pequeña población ubicada en la parte suroccidental de Colombia ${ }^{2}$, conformando, junto con otros nueve municipios, lo que actualmente se conoce como la subregión del norte del Cauca-sur del Valle del Cauca. Para principios del siglo XX basaba su economía en la producción y comercialización de bienes agrícolas propios de climas húmedos y cálidos, de los cuales destacaba el cacao (siendo en esta época el principal productor a nivel nacional). Históricamente, la producción cacaotera ya empezaba a ser importante desde las décadas finales del siglo XIX y así mismo el comercio con la ciudad de Cali. Aunque tanto producción como comercio eran actividades que cada vez cobraban más importancia entre las dos poblaciones, el tamaño del mercado - el cual era eminentemente local-y las políticas económicas

2 Puerto Tejada es un municipio ubicado en actual territorio del norte del Cauca-sur del Valle del Cauca, exactamente en el extremo norte del Departamento del Cauca, limitando con la zona sur del área metropolitana de Cali. En la actualidad cuenta con 50.000 habitantes aproximadamente según el índice de proyección del DANE elaborado en el censo nacional del año 2005, de los cuales el 97,5\% se reconoce como negro, mulato, afrocolombiano o afrodescendiente. Véase: Departamento de Administración Nacional de Estadística, "Perfil demográfico de Puerto Tejada - Censo 2005”, DANE, www.dane.gov.co/files/censo2005/ PERFIL_PDF_CG2005/19573T7T000.PDF. 
estatales, hacían difícil la acumulación de capital y en consecuencia inhibían una expansión económica sostenida ${ }^{3}$.

No fue hasta las primeras cuatro décadas del siguiente siglo que la producción de cacao empezó a ensancharse de una manera realmente dinámica y que en consecuencia Puerto Tejada llegara a convertirse en uno de los principales productores a nivel nacional, debido a la fuerte demanda de cacao para materia prima y alimentos ejercida desde Cali, ciudad que ya era capital del nuevo Departamento del Valle del Cauca (1910) y que además empezaba a configurarse como centro económico de toda la región suroccidental del Colombia, una ciudad-región, para tomar un concepto de Óscar Almario ${ }^{4}$. El comercio del cacao, en consecuencia, se tornó sumamente atractivo para empresarios, hacendados, negociantes y comisionistas. Prueba de ello fue la apertura de la ruta de vapores del río Cauca hasta Puerto Tejada, remontando el río Palo; la multiplicación de negocios y agencias interesadas en la comercialización del cacao; el mejoramiento y construcción de vías de transporte; y la expansión del casco urbano ${ }^{5}$.

Un efecto apreciable de esta bonanza coyuntural fue el acceso del campesinado portejadeño al dinero y también el mejoramiento moderado de su calidad de vida. Sin embargo, las condiciones sobre las que producía eran en muchos casos difíciles y particulares: si bien es cierto que en algunos casos tenían plena propiedad sobre la tierra y los cultivos, fue patrón constatado que la mayoría de las veces tenían derechos condicionados o incompletos sobre

3 Jacques Aprile, Los pueblos negros caucanos y la fundación de Puerto Tejada (Cali: Gerencia para el Desarrollo Cultural - Gobernación del Valle del Cauca, 1994), 103, 111-115; Mateo Mina, Esclavitud y libertad en el valle del río Cauca (Bogotá: Publicaciones La Rosca, 1975), 49,60 .

4 Para Almario, la confluencia de factores políticos, económicos, sociales, geográficos y político-administrativos, posibilitó la configuración moderna del Valle del Cauca y Santiago de Cali en las primeras décadas del siglo XX. Esta última, al concentrar los poderes económico y político, permitió la articulación de la región pacífica con el proyecto de modernización nacional así como con los mercados internacionales. Véase: Óscar Almario, "Cali y el Valle del Cauca: configuración moderna y reconfiguración contemporánea de la región y la ciudad-región”, en Historia de Cali, siglo XX. Política, coord. Esteban Morera (Cali: Programa Editorial Facultad de Humanidades, Universidad del Valle, 2012), 72-73.

5 César Zape, "Producción agrícola en el Norte del Cauca: agricultores del cacao en Puerto Tejada, 1916-1934" (tesis de Historia, Departamento de Historia, Universidad del Valle, 2014), 130-145. 
sus parcelas, las cuales estaban frecuentemente subsumidas en latifundios dominados por una élite hacendataria regional ${ }^{6}$.

El presente artículo no abordará este último proceso ni tampoco el estadio del comercio cacaotero; más bien enfatizará en los procesos y las formas de producción, así como en los diferentes tipos de relaciones sociales y la particular naturaleza de la propiedad de los campesinos nortecaucanos de Puerto Tejada.

Realmente, la historiografía regional no ha trabajado a fondo la cuestión campesina en el valle geográfico del río Cauca; por consiguiente, los estudios en esta materia para el caso de los territorios del norte del Cauca y las comunidades afrodescendientes que allí habitan han sido muy pocos. Existe, no obstante, un grupo pequeño de autores que, por un lado, han abordado la temática agraria en el valle del Cauca logrando identificar algunos sujetos agrarios (campesinos); $\mathrm{y}$, por otro, han hecho lo propio con algunos fenómenos económicos puntuales de la realidad histórica de Puerto Tejada y el norte del Cauca, en los que han estudiado tangencialmente los sujetos involucrados en la producción agrícola. En el primero de los casos podemos ubicar a los historiadores Eduardo Mejía y Armando Moncayo así como al geógrafo Luis Valdivia y al historiador Alonso Valencia; seguidamente, conviene resaltar las investigaciones circunscritas a Puerto Tejada del antropólogo Mateo Mina (Michael Taussig) y del urbanista Jacques Aprile.

En su investigación sobre la transformación de la hacienda tradicional vallecaucana a ingenio azucarero industrializado, Mejía y Moncayo, al dar cuenta precisamente de las condiciones socioeconómicas de dicho proceso transicional, se propusieron identificar y caracterizar someramente la categoría terrazguero. Para los historiadores, el terrazguero hacía parte de la realidad agraria del valle geográfico del Cauca en los siglos XIX y XX; estaba ubicado específicamente en espacios ribereños, caminos terrestres y pasos fluviales, en los intersticios territoriales de las grandes haciendas y sobre los límites de algunos caseríos o pequeñas poblaciones. Señalan además que las tierras a su cuidado oscilaban entre una y seis plazas de extensión, en las que el trabajo productivo era eminentemente familiar; las parcelas estaban conformadas por ranchos fabricados usualmente de paja y poseían cultivos de café, plátano, cacao y árboles frutales. En cuanto al uso productivo y comercial, destacan que el terrazguero gozaba del usufructo total de los cultivos, por lo tanto podía intercambiarlos en los mercados cercanos y/o en la misma hacienda; sin

6 Zape, "Producción agrícola en el Norte del Cauca: agricultores del cacao en Puerto Tejada, 1916-1934”, 157-166. 
embargo, a pesar de tener propiedad sobre los productos agrícolas, la tierra le pertenecía a los grandes hacendados ${ }^{7}$.

Cabe recalcar que Eduardo Mejía ha dedicado gran parte de su carrera académica a investigar el fenómeno campesino en la historia del Valle del Cauca y que en el marco del campo historiográfico de la región ha trabajado en exclusividad parte de la cuestión campesina en el valle geográfico del río Cauca en los siglos XVIII y XIX. A pesar de que solamente ha abordado las sociedades campesinas pertenecientes a la jurisdicción de la Buga colonial y republicana, son de destacar sus tesis de poblamiento y conflicto de cara a los procesos de formación de caseríos y posteriormente de municipios al margen de los territorios que ocupaban las haciendas tradicionales en dicha jurisdicción. De igual manera, son valiosos sus aportes con respecto a la caracterización de la vida campesina y las relaciones sociales de producción sobre la que ésta se desenvolvió. Estos presupuestos se encuentran sobre todo en Origen del campesinado vallecaucano: siglo XVIII y siglo XIX y en Campesinos, poblamiento $y$ conflictos: valle del Cauca 1800-1848.

En este orden de ideas, aunque Valdivia no enfatiza en la caracterización del campesinado vallecaucano, sí intenta dar cuenta del tipo de propiedad relacionada con éste. No es casualidad encontrar, en consecuencia, que en su obra abunde el término pequeñas posesiones para hacer referencia a pequeñas y medianas explotaciones familiares ubicadas en los límites de las haciendas, usualmente retiradas de los puntos de intercambio de productos agrícolas; caracterizadas además por ser resultado de un proceso de constitución a partir de la segunda mitad del siglo XVIII, en las cuales se producían cultivos de pancoger y se criaban ganados menores con fines tanto de subsistencia como de comercialización ${ }^{9}$. Esta última apreciación es a todas luces correspondiente y/o complementaria con las conclusiones de Mejía y Moncayo.

7 Armando Moncayo y Eduardo Mejía, "La transición de hacienda a ingenio azucarero industrializado en el valle del río Cauca. 1850-1923” (tesis de Licenciatura en Historia, División de Humanidades, Universidad del Valle, 1986), 98-101.

8 Eduardo Mejía, Origen del campesinado vallecaucano: siglo XVIII y siglo XIX (Cali: Editorial Facultad de Humanidades, Universidad del Valle, 1993), 149 p.; y “Campesinos, poblamiento y conflictos: valle del Cauca 1800-1848” (informe final de investigación Colciencias, Universidad del Valle, Facultad de Humanidades, Departamento de Historia, 2000), 209 p.

9 Luis Valdivia, Economía y espacio en el valle del Cauca: 1850-1950 (Cali: Universidad del Valle, 1992), 26, 143-149; Luis Valdivia, “Origen y situación de la pequeña posesión campesina en el Valle del Cauca, siglo XIX”, Historia y Espacio: Revista de estudios históricos y regionales 3, 10 (enero-junio 1994): 53-111. 
Por su parte, Alonso Valencia se interesó en la historia social y política del Departamento del Cauca a lo largo del siglo XIX, específicamente por las tradicionales élites políticas y económicas y el fenómeno del bandolerismo social en el contexto de las guerras civiles. En este sentido, fueron relevantes para la presente investigación sus libros Estado Soberano del Cauca: Federalismo y Regeneración y Marginados y “sepultados en los montes": orígenes de la insurgencia social en el valle del río Cauca, 1810-1830 ${ }^{10}$. Si bien ambos parten de preguntas diferentes y por lo tanto abordan problemas distintos, tienen en común que su autor ha hecho un esfuerzo por elaborar panoramas geográficos y socioeconómicos para caracterizar las diferentes zonas territoriales del viejo Cauca (siglo XIX) en función de sus particularidades socioeconómicas. Así, por ejemplo, fueron valiosas para esta investigación las zonas que concernían a las riberas de los ríos Cauca y Palo, lugares donde campesinos afrocaucanos estaban en plenos procesos de desesclavización y territorialización, comunidades que además basaban sus economías en la producción y el comercio de cultivos de pan-coger (cacao, café, plátanos) y tabaco.

Con el fin de explicar el proceso de fundación de Puerto Tejada, Aprile hizo un análisis del devenir histórico de los primeros pobladores que se asentaron en las riberas del río Palo en la segunda mitad del siglo XIX (cuya vocación era campesina), a partir de las relaciones sociales de producción que observó durante los distintos momentos históricos. El urbanista, en consecuencia, logra dar cuenta de dos sucesivas relaciones de explotación: la relación entre esclavizado y hacendado presente en las postrimerías del siglo XVIII y la primera mitad del XIX, que le dio paso a otra forma de explotación basada en la dominación económica y social de una élite terrateniente (descendientes directos de los hacendados) sobre una vasta población terrazguera (descendientes directos de los esclavizados) hasta bien entrado el siglo XX ${ }^{11}$.

Esta última situación también la encontramos en Esclavitud y libertad en el valle del río Cauca, ese ya canónico estudio de Mateo Mina (Michael Taussig) sobre la historia de la explotación negra en el norte del Cauca y en especial Puerto Tejada. El antropólogo aborda básicamente los procesos conflictivos presentes en la historia social y económica de los campesinos de Puerto Tejada,

10 Alonso Valencia, Estado Soberano del Cauca: Federalismo y Regeneración (Bogotá: Banco de la República, 1988), 297 p.; y Marginados y “sepultados en los montes": orígenes de la insurgencia social en el valle del río Cauca, 1810-1830 (Cali: Programa Editorial Universidad del Valle, 2008), $214 \mathrm{p}$.

${ }^{11}$ Aprile, Los pueblos negros caucanos y la fundación de Puerto Tejada, 227. 
caracterizados por tener un primer momento que enfrentó a la población esclavizada en las haciendas tradicionales de la margen oriental del río Cauca contra los terratenientes esclavistas (durante buena parte del siglo XIX) para que, seguidamente, prosiguiera el mismo tipo de confrontación esta vez entre terrazgueros y hacendados durante buena parte del $\mathrm{XX}^{12}$. Es justo destacar además que no solamente abarca el conflicto desde la variable socioeconómica, también lo problematiza desde el desencuentro de dos diferentes tipos de racionalidades: una campesina afronortecaucana y otra mercantil, más cercana a los terratenientes-empresarios del siglo XX; apelando a ciertos principios e instituciones afrocampesinas con el fin de argumentar las formas de la penetración capitalistas pero también las estrategias de resistencia en la vida cotidiana frente a éste sistema.

Salvo las menciones que se encuentran en este último estudio en torno al campesinado portejadeño de inicios del siglo XX así como algunos aspectos que destaca Aprile en su ya citada obra en el mismo sentido-baste decir que ambos trabajos no se proponen responder a preguntas relacionadas con la realidad campesina de dicho contexto-, existe una ausencia total de investigaciones desde las Ciencias Sociales que nos acerquen al mundo rural del norte del Cauca y sur del Valle del Cauca en la primera mitad del siglo XX. Es por lo tanto necesario y urgente hacer esfuerzos en este sentido con el fin de, por un lado, abrir para el campo disciplinar una realidad sociohistórica casi por completo invisible $\mathrm{y}$, por otro, tornar más compleja la historia social y económica del valle geográfico del río Cauca en el siglo XX. Este artículo debe entenderse en este sentido.

\section{¿Qué tipo de campesino había en Puerto Tejada en las primeras décadas del siglo XX?}

Antes de comenzar este aparte, es necesario hacer una advertencia. Ante la falta de trabajo empírico y teórico sobre la realidad agraria del norte del Cauca y sur del Valle del Cauca a inicios del siglo XX, un intento por definir el tipo de campesino presente en ese contexto representa un ejercicio de cierta complejidad. Sin embargo, he planteado esbozar una caracterización que me permita aproximarme teóricamente al objeto de estudio. El propósito es sencillo: dotar conceptualmente este fragmento de la investigación de rigurosidad y concreción, sin pretender encapsular en un cúmulo de ideas "científicas" la realidad, pero tampoco dejar que al empirismo se le escurran

${ }^{12}$ Mina, Esclavitud y libertad en el valle del río Cauca, 165. 
los modelos de interpretación. En este sentido, la ciencia nunca podrá abstraer y mucho menos explicar toda la realidad, y esta última, en términos del conocimiento, sería incomprendida sin la interpretación científica, si por realidad entendemos el espacio de la percepción o el campo de la experiencia que ya se encuentra simbolizado ${ }^{13}$. Antes que meterse en la ingenua $-\mathrm{y}$ por lo demás violenta-operación de abstraer el complejo ámbito de la experiencia mediante el reducido campo de los conceptos, hay que tener presente que es la misma experiencia la que nos permite construir y orientar la teoría ${ }^{14}$.

${ }^{13}$ La relación entre el saber científico y la experiencia (realidad) planteada por Yannis Stavrakakis, desde el punto de vista de la teoría lacaniana, ha resultado de gran ayuda. El autor menciona: "La teoría sólo puede manifestarse como una adecuación o representación veraz de la experiencia si el campo de la experiencia se reduce a aquello que ya está simbolizado; en el mejor de los casos, a lo que es simbolizable de acuerdo con las reglas prevalecientes de la simbolización: en términos lacanianos, si lo 'real' se reduce a la 'realidad' (que de acuerdo con Lacan se construye en los niveles simbólico e imaginario, mediante el significante y la imagen) [En nuestro caso, imagen fragmentada de una realidad que ya no está]. Entonces, aquí no se disputa el hecho de que el saber pueda ser fiel a la realidad; claro que puede serlo. Sólo que se trata de una realidad ya producida mediante las reglas científicas de la simbolización, una realidad ya teorizada (...) El discurso de la ciencia suele consagrarse a la representación y explicación de este campo de la experiencia domesticada, el campo de lo que podría llamarse 'experiencia banal' (...) Dentro del esquema de la ciencia normal [el autor se refiere a la noción de Thomas Kuhn], todos los encuentros con lo real, con la 'anomalía' ('lo que ha violado las expectativas inducidas por el paradigma que gobierna la ciencia normal'), terminan por reducirse a lo 'esperado'. Véase: STAVRAKAKIS, Yannis Stavrakais, Laizquierda lacaniana: psicoanálisis, teoría, política (Buenos Aires: Fondo de Cultura Económica, 2010), 25-26. Lo real en Lacan se corresponde con los 'extramuros' del discurso (científico) planteado por Michel Foucault. Esa 'anomalía', esa porción de lo real que aflora en algún momento, no es otra cosa que un enunciado extraño (una 'monstruosidad') que está por fuera (en su momento) de los límites del discurso, es decir, por fuera de la verdad científica del paradigma que gobierna, así sea validado posteriormente. Foucault decía, para el ya conocido caso de Gregor Mendel, que éste "decía la verdad pero no estaba 'en la verdad". Véase: Michel Foucault, El orden del discurso (Barcelona: Tusquets Editores, 2010), 36-38.

${ }^{14}$ Como decía Pierre Bourdieu mientras construía su arsenal conceptual a partir de la experiencia con las sociedades argelinas de la Cabilia: "Esta reflexión [teórica] sobre la práctica científica está realizada para desconcertar tanto a aquellos que reflexionan sobre las ciencias del hombre sin practicarlas, como a aquellos que la practican sin reflexionar. La práctica científica no escapa a la teoría de la práctica que aquí se propone: los mejores prácticos pueden tener la habilidad práctica de las operaciones científicas sin disponer del tiempo libre ni de los instrumentos necesarios para salir de esta docta ignorancia; los especialistas de la reflexión epistemológica o metodológica están necesariamente condenados a considerar más bien el opus operandi que el modus operandi, lo que implica, además de un cierto retraso, 
Procesos y formas de producción campesina en el norte del Departamento del Cauca: agricultores. César Enrique Zape Jordán

Con esa misma intención teórica propongo abordar el análisis de la propiedad y las relaciones sociales en torno al proceso de la producción de cacao a inicios del siglo XX en el norte del Cauca-sur del Valle del Cauca. Y no es para menos, ya que se encuentran formas de propiedad peculiares, caracterizadas por encontrarse a mitad de camino entre una estructura agraria de rezago colonial y otra que abrazaba tímidamente las reformas liberales, sobre todo entre campesinos que laboraban en minúsculas unidades agrarias.

Quiero dejar claro que para emprender la tarea de caracterizar o aproximarme teóricamente al sujeto campesino nortecaucano de inicios del siglo XX, partiré de la realidad observable a través de la documentación de que dispuse. A pesar de algunas limitaciones de tipo formativo y las ya mencionadas teóricas y empíricas, a continuación le extiendo la propuesta al lector.

Es un campesino cualquier persona que pertenezca a una comunidad rural o agraria, que se legitime social y políticamente en tanto pertenezca a ésta y que desarrolle actividades productivas (prácticas agrícolas y/o pecuarias) dentro de ese contexto. Dichas actividades pueden tener fines relacionados con la subsistencia, el comercio o con ambos simultáneamente. La gestión técnica de la producción la realiza sobre una unidad de producción-consumo con base en trabajo familiar, sea ésta propia o no ${ }^{15}$; la tierra que es medio material de subsistencia, también es parte de la vida social y simbólica del campesino: ella es el eje de su vida cotidiana, en no pocos casos el legado de sus ancestros y la herencia de sus hijos.

Generalmente, el concepto de campesino suele asociarse a jornalero, aparcero, estanciero, finquero, medianero, agricultor, arrendatario, etc., y se ha definido genéricamente como aquella persona, hombre o mujer, que basa su tiempo de trabajo y por lo tanto su subsistencia expresamente en las labores

un sesgo sistemático”. Pierre Bourdieu, Bosquejo de una teoría de la práctica (Buenos Aires: Prometeo Libros, 2012), 173.

${ }^{15}$ Es útil revisar la definición de Víctor Breton al respecto: "El mínimo común denominador de las sociedades campesinas constaría, en términos generales, de tres factores imprescindibles: la explotación agraria familiar, que constituye al mismo tiempo la unidad esencial de acción social y de la vida económica; la aldea, marco donde operan las explotaciones domésticas y donde se desarrollan las relaciones sociales; y los vínculos con el mundo exterior. Son elementos fundamentales en este último ámbito las plazas de mercado, a través de las cuales los agricultores obtienen artículos y servicios no producidos por ellos (...)”. Para profundizar en aspectos referentes a la teoría campesina, sugiero revisar: Víctor Breton, “ ¿De campesino a agricultor? La pequeña producción familiar en el marco del desarrollo capitalista”, Historia Agraria: revista de agricultura e historia rural 5 (1993): 134. 
que tienen que ver con las prácticas agropecuarias. Es un sujeto que vive en el campo y también de este, y como tal, pertenece socialmente a una comunidad agraria o rural; usa técnicas y herramientas sencillas para explotar los recursos de la tierra y también los animales. El despliegue de estas actividades es llevado a cabo casi siempre pero no exclusivamente por los miembros de su familia; en algunas ocasiones por otros campesinos (jornaleros sin tierra a los que se les pagaba por día de trabajo, por ejemplo) y, en no pocos casos, por vecinos que forman redes de ayuda mutua, las cuales se reproducen a través de intercambios simbólicos y materiales basados en los principios colaboracionistas, sobre parcelas propias o ajenas ${ }^{16}$.

Pues bien, para el caso de Puerto Tejada a inicios del siglo XX y después del respectivo análisis documental y del acercamiento a la comunidad de estudio, encontré que dentro de la categoría campesino, el concepto que más se acerca al fenómeno concreto es el de agricultor, entendiendo por éste un tipo de campesino dedicado casi que exclusivamente a los cultivos vegetales; sin embargo usaré esta noción de manera referencial, más bien como un punto de partida desde el que pueda hacer un ejercicio de aproximación conceptual a partir de la práctica ${ }^{17}$.

Sostengo que el agricultor en el Puerto Tejada de principios del siglo XX era único y particular, debido a su irrepetible proceso histórico, económico,

${ }^{16}$ Marco Palacio plantea una definición más exhaustiva y específica del concepto de campesino que ha sido tenida en cuenta para esta investigación. Este autor hace un esfuerzo por distinguir y explicar las diferentes clases de campesinos. El mismo autor menciona, para el caso de la naturaleza de la propiedad de la tierra, que "es una relación social, una praxis de su acceso, conservación y mejora que, en el caso de la propiedad campesina, primero se legitima en el tejido de los vecindarios y sólo después, y eventualmente, en las instituciones del Estado". Este mismo proceso, con algunas diferencias, caracterizó la evolución de la propiedad en Puerto Tejada y el norte del Cauca. Más adelante nos referiremos desde lo concreto. El grueso de la propuesta de Palacios está en: Marco Palacios, ¿De quién es la tierra? Propiedad, politización y protesta campesina en la década de 1930 (Bogotá: FCE, Universidad de los Andes, 2011), 51-54, 71.

17 La noción agricultor no hubiera podido ser construida sin los testimonios de quienes desempeñaron y desempeñan esa función: los campesinos de Puerto Tejada que, en efecto, se llaman a ellos mismos agricultores y que brindaron sus testimonios para completar el panorama documental del artículo, en especial de este aparte. Cabe recordar que la base documental sobre la que hice la caracterización del campesinado portejadeño de inicios del siglo XX fue producto del análisis de fotografías y fuentes orales, recolectadas a partir de entrevistas con Maura Elisa Díaz, Ángel María Viveros, Daniel Velasco, Aurelio Cabal, Luis Emir Ambuila y Rosember Mina. 
Procesos y formas de producción campesina en el norte del Departamento del Cauca: agricultores. César Enrique Zape Jordán

social y cultural. Afrodescendiente y asentado históricamente en el norte del actual Departamento del Cauca, habitaba un espacio de referentes físicoterritoriales de planicie húmeda y selvática ${ }^{18}$; estaba tradicionalmente dedicado al cultivo de productos de pan-coger y sus antepasados laboraban en haciendas basadas en relaciones sociales de producción esclavistas entre mediados de los siglos XVIII y XIX, los cuales eran manumisos o se encontraban evadidos o fugados. Al mismo tiempo que parecían estar privados de hacerse con su propia humanidad, estaban llevando a cabo un doble proceso de esclavizacióndesesclavización que tenía su correlato en un desarrollo incontenible de formas de territorialización (basadas en prácticas de libertad, formas de reproducción familiar y configuración de patrimonios espaciales) a partir del control políticoeconómico y la apropiación simbólica de espacios ${ }^{19}$ que en términos formales les pertenecían a las haciendas esclavistas de la época.

Dependía materialmente del trabajo agropecuario y se legitimaba social y políticamente en tanto perteneciera a un lugar significado y construido histórica, simbólica y socialmente por los sujetos que lo componían. Este era el espacio de identidad o identificación rural pero también de diferenciación social y dominio sobre los recursos naturales (un territorio) ${ }^{20}$, que para nuestro caso se correspondía con un vecindario, caserío, vereda, etc.

El agricultor portejadeño se dedicaba, en términos generales, a las labores del cultivo de productos vegetales para fines de consumo familiar pero también con intereses comerciales. Se servía, además, de la actividad pecuaria pero en un grado más bien marginal y tendía a ser una labor cuyo producto complementaba la dieta del hogar. Usualmente esta actividad tenía que ver con la cría de animales pequeños como gallinas y cerdos. Los caballos y vacas tenían poca presencia; no obstante, algunos agricultores - en realidad muy pocos-llegaron a tener potreros o "mangas" de reducido tamaño con el aparente fin de negociar ganado a muy pequeña escala ${ }^{21}$.

18 Son referentes territoriales los lugares que sirven como medio para el despliegue de procesos de territorialización y estrategias de localización: ríos, montañas, desiertos, selvas, etc. Para más profundidad, véase: José Ángel Rodríguez, "El hombre en el espacio”, en Visiones del oficio: Historiadores venezolanos en el siglo XXI, comp. José Ángel Rodríguez (Caracas: Fondo Editorial de Humanidades y Educación - Universidad Central de Venezuela, 2000), 41-42.

19 Rogério Haesbaert, Territórios Alternativos (São Paulo: Contexto, 2006), 120-121.

20 Según las definiciones de Haesbaert, Territórios Alternativos, 121-122 y Joël Bonnemaison, La géographie culturelle (Paris: Comité des travaux historiques et scientifiques, 2000), 131.

${ }^{21}$ Maura Elisa Díaz precisaba: "Mi papá no vendía las cosas, mi mamá se encargaba de que los huevos fueran para la casa, si se vendía pues se vendía lo que sobraba (...) Para sacar leche, 
El agricultor portejadeño de inicios del siglo XX tenía un pie dentro del mercado y por consiguiente en el ámbito urbano y otro en el universo de unas prácticas agropecuarias ancestrales y familiares localizadas en el contexto de la comunidad rural. Estaba triplemente interesado en la ganancia monetaria, en la consecución de la propiedad sobre la tierra (por medio, en la mayoría de las ocasiones, de un contrato denominado terraje) y en el bienestar tanto de su familia como de su comunidad; intereses que eran más bien complementarios y mixtos ${ }^{22}$. La ganancia monetaria le servía como medio de intercambio para complementar la dieta - en realidad para acceder a alimentos no producidos en el marco de la finca- o para adquirir productos manufacturados, como ropa, herramientas y utensilios propios del trabajo agrícola ${ }^{23}$. La publicidad en Norte, rotativo liberal de la década de 1930 de circulación en Puerto Tejada, indica que había demanda de estos bienes: "Jorge Zúñiga. Comerciante. Almacén Plaza Chiquita. Compras y ventas de cacao y café. Ofrece artículos de abarrotes, licores y granos. Especialidad en machetes, palas, barretones, alambre de púas, metales y muchos otros artículos que a usted le convienen (...)"24.

El agricultor, además, necesitaba producir y vender cacao, café, plátanos y mejoras para ir pagando su propiedad o la cuota de arrendamiento, así como también proveer de bienestar material a su familia y divertirse ${ }^{25}$. Deambulaba,

se sacaban de las mejores vacas; esa leche era para la casa (...) El ganado que no se vendía se pelaba”. Maura Elisa Díaz, entrevista personal, Puerto Tejada, 16 de diciembre de 2013.

${ }^{22}$ Karl Polanyi, "Nuestra obsoleta mentalidad de mercado", Cuadernos de Economía 14, 20 (primer semestre de 1994): 255.

${ }^{23}$ Daniel Velasco rememoraba: "en ese tiempo [década de 1920] mi papá compraba la herramienta en Cali, una parte venía de Alemania y otra de Estados Unidos (...) allí compraba usted el revólver, la escopeta, municiones, de todo (...) había la máquina de escribir Remington, Underwood y después otra que llamó Corona, la máquina de coser era Jones, después la máquina de coser más importante que hubo: la Singer; y después la Pfaff”. Daniel Velasco, entrevista personal, Puerto Tejada, 14 de diciembre de 2013. Ángel Viveros también comentaba que "en las faenas de la tierra usábamos machete, pala, barretón, hacha para rajar leña y tumbar palos". Ángel María Viveros, entrevista personal, Puerto Tejada, 16 de diciembre de 2013.

${ }^{24}$ Norte, 25 de abril, 1934, 3.

${ }^{25}$ Los campesinos "mantenían en billares tomando tinto, café en leche y jugando. Los hijos [de estos campesinos] se iban a estudiar a Bogotá”, afirmaba Eddie Azcárate. Eddie Azcárate, entrevista personal, Puerto Tejada, 14 de diciembre de 2013. Daniel Velasco mencionaba, por otro lado, que "había individuos que tenían un cuarto de tierra [plaza] (...) trabajaban y vivían de ese cuarto de tierra, bebían aguardiente, vestían y demás y ahorraban”. Velasco, entrevista personal. 
Procesos y formas de producción campesina en el norte del Departamento del Cauca: agricultores. César Enrique Zape Jordán

en consecuencia y según fuera el caso, entre el caserío/vereda, los mercados locales, ríos, puertos fluviales e incluso en centros de comercio de importancia regional como el de Santiago de Cali. Los mercados o "plazas" eran espacios en donde se desplegaban los intercambios materiales así como los encuentros y socializaciones interpersonales. Estos lugares permitieron la articulación entre producción y comercio agrícola y como tal, significaron la parte más dinámica de la economía campesina ${ }^{26}$. En estos espacios no solamente confluían mercancías, también interactuaban sujetos que llevaban las cosechas de cacao, café y plátano desde las veredas circunvecinas hasta el pueblo, para después completar el proceso circulatorio hasta Cali.

En muchos aspectos el agricultor evitaba la intermediación comercial indirecta para acudir al centro mayorista (Puerto Mallarino, en Cali) ${ }^{27} \mathrm{y}$, acudiendo a los saberes de sus antepasados, armaba balsas de guadua ${ }^{28} \mathrm{y}$ alistaba mulas para completar el embalaje y transporte de sus propios productos muchas veces arriesgando su propia vida. Esta situación plantea al menos dos conclusiones: que la función económica del intermediario comercial aún no se había generalizado y que además del saber agropecuario, el campesino portejadeño también poseía y acumulaba uno comercial y geofísico, en tanto que sabía de precios y medidas así como de ríos y caminos.

${ }^{26}$ Vale la pena destacar la definición que nos ofrece T. Shanin al respecto: "Las plazas de mercado están típicamente relacionadas con condiciones en que una gran parte de las mercancías nunca llegan al mercado, pues son consumidas dentro de las unidades familiares. En este sentido, los mercados forman un componente típico del sistema campesino de organización económica, proveyendo un lugar donde los productores primarios venden parte de su producción para obtener dinero en efectivo y complementar la producción hogareña (...) Las plazas de mercado también cumplen una serie de funciones 'no-económicas', como centros de contacto inter-aldeano, información, vida social y esparcimiento". Véase: Teodor Shanin, Naturaleza y lógica de la economía campesina (Barcelona: Editorial Anagrama, 1976), 29-30.

${ }^{27}$ La presencia de avisos de casas chocolateras en la prensa sugiere este hecho: "Cacao! (sic) Señor cultivador: La Cía. Nacional de Chocolates compra permanentemente cacao. Seleccione usted el grano para que obtenga mejor precio. Las oficinas y depósitos de la Compañía están situados en la Avenida Uribe Uribe, frente al Manicomio". Véase: Relator, 2 de marzo, 1931, 2. En este mismo sentido, Eddie Azcárate recordaba: "La Luker, en Cali quedaban las sedes, compraba el cacao y le entregaba a usted como comprador de cacao una millonada. El jueves o viernes estaba entregando usted unos dos o tres camiones llenos de cacao a la Luker”. Eddie Azcárate, entrevista personal.

28 Ángel María Viveros recordaba que su padre era un "bajador”, es decir, un agricultor que solía embalar y transportar su propia producción con fines comerciales. La existencia del término revela que el campesinado construía su propio lenguaje. Viveros, entrevista personal. 
Vale la pena usar una crónica trágica publicada en El Día, periódico liberal caleño, ocurrida en 1913, para acercar al lector al contexto del transporte, las vías y el comercio en aquellas épocas. De igual manera esperamos completar este ejercicio con el testimonio y las dos figuras (Figura 1 y Figura 2) que le siguen:

Hace pocos días ocurrió en el Cauca un horripilante suceso trágico. De Puerto Tejada venía una familia con todo su equipo en dos balsas unidas. Navegaban en la madrugada del viernes cuando, probablemente por la oscuridad de la hora, chocaron las balsas con una palizada y a consecuencia del choque se volcaron. Todos los pasajeros se hallaban durmiendo y despertaron dentro del agua ${ }^{29}$.

Balsas amarradas unas tras de otras con productos embarcados con destino hacia Cali, encuentran correspondencia en las palabras que Ángel María Viveros compartía:

En ese tiempo la carga de aquí era transportada por balsas. Mi papá era 'bajador'; él se amarraba tres o cuatro champanes y con su canalete se agachaba e iba guiando la balsa (...) El cacao de aquí y el plátano iba a Cali por balsa; la balsa es un champán de pura guadua. Estaban amarradas tres o cuatro balsas y él le ponía el canalete para remar y guiar al mismo tiempo ${ }^{30}$.

Figura 1. Campesinos en balsas de guadua (champanes) sobre el río Palo



Fuente: Archivo personal de la señora Isabel Ararat. La fotografía fue tomada en 1939 aproximadamente.

${ }^{29}$ El Día, 21 de mayo, 1913, 3.

${ }^{30}$ Viveros, entrevista personal. 
Procesos y formas de producción campesina en el norte del Departamento del Cauca: agricultores. César Enrique Zape Jordán

En la anterior fotografía sobresalen varios agricultores en balsas pequeñas de guadua en el río Palo (afluente a pocos kilómetros del Cauca), la mayoría con sombreros, camisas claras, pantalones oscuros (vestimenta típica) y sin calzado. Podemos ver que todos usaban el canalete para gobernar la balsa, de acuerdo con las anteriores palabras de Ángel María Viveros. También había presencia de personas en las márgenes del río, sobre todo a la derecha, lo cual sugiere que este punto era un malecón de champanes. Imagen registrada en 1939 aproximadamente.

Figura 2. Mercado de balsas en Puerto Mallarino



Fuente: Mercado de balsas de guadua procedentes de Puerto Tejada en Puerto Mallarino a comienzos del siglo XX (la fotografía fue tomada entre 1935 y 1940, aproximadamente). El río en el que reposan las balsas es el Cauca. Se pueden observar, además, algunos campesinos encima de las embarcaciones.

Sin embargo, esta doble actividad no constituía la regla. En ocasiones los agricultores recurrían a los comerciantes establecidos en la cabecera quienes, a su vez, vendían los productos en el mercado caleño, tal como lo relataba Maura Elisa Díaz: "Mi papá cosechaba el cacao y se lo vendía a los comerciantes acá en el Puerto, lo vendía a la Federación de cacaoteros porque la Federación también tenía puestos de compras de cacao(...)" ${ }^{\prime 31}$. Karl Polanyi señalaba, parafraseando a Aristóteles, que no se debe pensar al campesino como un individuo por fuera del mercado (de la antigüedad europea), como si de un ermitaño romántico y autosuficiente se tratara. Éste, más bien, se proyecta en dos frentes: en el espacio de la producción tradicional y parcelaria pero también en el espacio

${ }^{31}$ Díaz, entrevista personal. 
del intercambio. La cuestión, insistía Polanyi, es rastrear el móvil, los intereses de sus comportamientos y transacciones - sociales, simbólicos, económicos, etc. -, y bajo qué sistema de valores o principios operaban ${ }^{32}$.

No tenía entonces el agricultor portejadeño de principios del siglo XX una racionalidad propiamente mercantilista y eso lo demuestran de manera clara sus relaciones comunitarias - basadas en la institución de la familia extensa ${ }^{33} \mathrm{y}$ forjada bajo principios de colaboración como la minga y el cambio de mano-y la naturaleza de su nexo con la tierra ${ }^{34}$. Formaban este conjunto de relaciones un ethos campesino afronortecaucano que reafirmaba una racionalidad material y simbólica tradicional al mismo tiempo que contrastaba con los preceptos socioeconómicos del liberalismo y con ello el influjo violento del capitalismo sobre la tierra y el trabajo. Existían, de hecho, dos concepciones sobre el trabajo y la propiedad fuertemente opuestas: una contradicción ideológica y material entre un proyecto económico nacional y unas formas de producción de lo material y lo simbólico basadas en dicha ética tradicional afrocaucana con expresión en lo local. La tierra, por ejemplo, se comportaba como un bien material de subsistencia y comercio pero también como patrimonio social-familiar, espacial y simbólico. Venderla, en consecuencia, podría llegar a ser inmoral, así como también supondría eventualmente poner en riesgo la

32 Véase: Karl Polanyi, La gran transformación: crítica del liberalismo económico (Madrid: Ed. de la Piqueta, 1997), 98-99.

${ }^{33}$ Refiriéndose a las familia característica afrodescendiente del sur del valle geográfico del río Cauca en el siglo XIX, el historiador Mario Diego Romero menciona: “La familia negra en el sur del valle del río Cauca, en Colombia, se establece en el referente primordial de cualquier integración social y de identidad sobre la base de, por lo menos, cinco aspectos comunes y generales: uno, el común origen africano; dos, la común condición social de descendientes de esclavizados; tres, los comunes atributos fenotípicos negros; cuatro, su común adscripción territorial a las haciendas esclavistas; y cinco, sus comunes elementos culturales. Tal como lo habrían hecho las sociedades domésticas africanas, refrendaron sus aspectos comunes al establecer los lazos parentales, de linajes y de consanguinidades. Véase: Mario Diego Romero, "La familia" (Cali: Universidad del Valle, 2013), 4. El autor agrega, para el mismo contexto, que se puede observar "en las familias negras del sur del valle del río Cauca, dinámicas de inserción de los esclavizados en construcciones territoriales, culturales, económicas y sociales a las que se adscriben con sentidos identitarios como pueblos y comunidades. Allí la familia traspasa los lazos parentales en sí, hacia las interacciones y alianzas para la preservación del territorio y la identidad cultural. Véase p. 9 del mismo texto. Este es un capítulo inédito que conforma sólo una parte de una obra más grande aún sin publicar resultado de la tesis doctoral del autor. El profesor Romero gentilmente decidió proporcionar el texto.

${ }^{34}$ Mina, Esclavitud y libertad en el valle del río Cauca, 21 y 81. 
integridad física y simbólica de la familia (su identidad), ya que no solamente no se podría heredar sino que también se perdería el "contacto" con los ancestros ${ }^{35}$.

La unidad familiar es, en consecuencia, el medio para preservar la descendencia y asegurar la reproducción material de los bienes. Para el agricultor portejadeño de inicios del siglo XX la tierra era como la familia misma: remitía a una ética que bloqueaba su fragmentación y mercantilización; así mismo, dicha ética actuaba directamente sobre sus formas de intercambio básicamente en dos direcciones: como mencionaba hace un momento, por una lado diluía la función económica del intermediario, gracias a la posibilidad que tenía de interactuar independientemente en los niveles de la producción y comercialización; por otro, limitaba la acción del mercado sobre sus aspectos vitales, al consagrar el producto de la huerta y la actividad pecuaria al bienestar material de los miembros de su familia. En ambos casos, lo producido -junto con la ética que envolvía dicha acción-generaba alternativas económicas que evitaban la apelación directa e inevitable al mercado.

Sin embargo, no sería prudente afirmar que esta situación fuera absoluta, ya que a través de la documentación revisada sobresalen bastantes casos en los que se vendían pequeñas propiedades ${ }^{36}$ así como campesinos acudiendo directamente a los comerciantes más cercanos. ¿Qué estaba pasando? Básicamente, una vez en marcha el proyecto de modernización a nivel nacional y regional, se empezaron a configurar relaciones de poder que paulatinamente fueron definiendo la sociedad bajo un esquema liberal, en términos de valores, principios y comportamientos. Supuso esta situación un cambio sutil pero dramático y permanente, a través de un proceso continuo de violencia simbólica ${ }^{37}$. El proyecto de modernización colombiano fue capitalista y la base política sobre el cual se legitimó, liberal. El capitalismo se apoyó sobre la

35 “Teníamos cacao pero se cultivó sobre todo en las otras fincas [propiedades de su padre], en Primavera y en Tierradura, mientras nosotros nos quedábamos con mi mamá en la finca, mi papá y sus hermanos se iban a cosechar cacao a Primavera y de ahí a Tierradura, porque cuando a ellos se les murieron los papás no se repartieron [ni la familia ni la tierra] sino que siguieron allí unidos (...) Como tenían toda la tierra unida [la familia] y no se había repartido (...)", mencionaba Maura E. Díaz. Díaz, entrevista personal.

${ }^{36}$ Centro de Investigaciones Históricas José María Arboleda Llorente -Archivo Central del Cauca- (en adelante ACC) Universidad del Cauca, Fondo Notarial, Notaría Única de Puerto Tejada, t. 1920, 1923, 1925, 1930, 1934. Documentación correspondiente a protocolos notariales de compraventa de propiedades rurales.

${ }^{37}$ Al respecto, Pierre Bourdieu menciona: "Mediante el concepto de violencia simbólica trato de hacer visible una forma de violencia cotidiana no percibida”. Véase: Pierre Bourdieu y 
filosofía política liberal y la teoría económica clásica, desplegando un nuevo tipo de racionalidad que se fue legitimando socialmente por medio de un proceso de interiorización y naturalización de una ética particular y diferente. Por otra parte, se impuso el interés exclusivo del lucro fundamentado en una competencia individual por llegar a los mercados.

En consecuencia, las relaciones comunitarias y el nexo simbólico con la tierra terminaron por reacomodarse según las nuevas lógicas, obligando muchas veces a comportamientos y situaciones antes desconocidos como el uso de la tierra con fines exclusivos de lucro por venta o arrendamiento ${ }^{38}$.

\section{La producción agrícola campesina en Puerto Tejada en las primeras déca- das del siglo XX: unidades de producción-consumo, relaciones sociales y formas de propiedad}

El agricultor portejadeño llevaba a cabo su trabajo productivo en una porción de tierra pequeña llamada parcela, la cual era parte fundamental de la finca (también llamada finca rural, finca agrícola o finca de campo), unidad de producción-consumo tradicional campesina de la Puerto Tejada de inicios del siglo XX. Era sobre la parcela en donde se sembraban, crecían, maduraban y se cosechaban los cultivos que generalmente se comercializaban, como el cacao y el café, en muchos casos bajo peculiares formas de propiedad sobre las fincas y exhibiendo relaciones sociales asimétricas en el ámbito productivo, consecuencia del dominio de una élite hacendataria en el territorio.

Terry Eagleton. “Doxa y vida cotidiana: una entrevista”, en Ideología: un mapa de la cuestión, comp. Slavoj Žižek (Buenos Aires: Fondo de Cultura Económica, 2003), p. 296.

${ }^{38}$ Es útil en esta parte referirse al momento en el que este tipo de interés terminó definiendo las relaciones sociales del mundo moderno, ya que, para nuestro caso, las lógicas relacionales de la sociedad y la economía estaban transformándose. A propósito, Polanyi, desde una crítica al liberalismo económico en la Europa de 1945-1950, planteaba: "A pesar de los cánticos laudatorios de carácter universitario que se dejaron oír a lo largo del siglo XIX, las ganancias y beneficios extraídos de los cambios jamás habían desempeñado con anterioridad un papel tan importante en la economía humana. Pese a que la institución del mercado había sido, desde el final de la Edad de piedra, un hecho corriente en las sociedades, su papel en la vida económica siempre había sido secundario (...) por lo general las relaciones sociales de los hombres engloban su economía. El hombre actúa, no tanto para mantener su interés individual de poseer bienes materiales, cuanto para garantizar su posición social, sus derechos sociales, sus conquistas sociales". Véase: Polanyi, La gran transformación: crítica del liberalismo económico, 83-88. A propósito de los principios de la minga y el cambio de mano (relaciones sociales en base al colaboracionismo) para el caso particular, es indispensable revisar: Mina, Esclavitud y libertad en el valle del río Cauca, 92. 
Procesos y formas de producción campesina en el norte del Departamento del Cauca: agricultores. César Enrique Zape Jordán

\section{Tipos de fincas en Puerto Tejada: una aproximación}

Como tal, la finca representaba un marco de posibilidades. No era una unidad que servía meramente para la producción incesante de bienes primarios comercializables, más bien era un pequeño universo simbólico y cultural insertado en un complejo territorial de carácter campesino-comunitario ${ }^{39}$.

Los protocolos notariales, medios en los que se formalizaban las transacciones más frecuentes, son un instrumento básico para reconstruir el tipo de unidad campesina nortecaucana. Estas escrituras solían contener descripciones básicas y muy concretas de las fincas en compraventa. En la siguiente, por ejemplo, encontramos referencias a una unidad promedio:

En la población de Puerto Tejada, Circuito de notaría del mismo nombre, provincia de Camilo Torres, Departamento del Cauca, República de Colombia, a los veintiun días del mes de mayo de mil novecientos veinte (...) compareció el señor Alejandro Guevara (...) y dijo, Primero: Que dá en venta real y enajenación perpetua al señor Virgilio Rizo (...) una finca rural sita en el punto de Campoalegre, jurisdicción de este Distrito de Puerto Tejada, finca que se halla en terrenos del señor Guillermo Garcés, y que se compone de unos mil árboles de cacao, poco más o menos, plátano, café, palmicha, árboles frutales como limones-naranjas, caimitos, y una manga de pasto artificial (pará) en una superficie de dos y media plazas, y casa de habitación construida de guadua, todo lo cual se halla bajo los siguientes linderos: al Occidente: el río Cauca; al Norte: fincas de Samuel Sánchez y Simón Balanta; al Oriente: potrero del señor Guillermo Garcés; y al Sur: terrenos del mismo señor Garcés. Segundo: Que se hace la venta de la expresada propiedad (...) por la cantidad de mil seiscientos pesos $(\$ 1.600,00)$ oro legal $(\ldots)$ Tercero: Que la propiedad o mejoras que enajena por medio del presente público instrumento, las adquirió por haberlas cultivado con sus propios fondos $(. . .)^{40}$.

La imagen de la finca en Puerto Tejada para las primeras décadas del siglo XX, sin embargo, no es suficiente. Considero que la mejor forma para

${ }^{39}$ Una definición básica la ofrece Teodor Shanin: "La explotación campesina forma una pequeña unidad de producción-consumo que encuentra su principal sustento en la agricultura y es sostenida, principalmente, por el trabajo familiar. Las necesidades de consumo familiar y las deudas contraídas con los detentadores del poder político-económico definen en grado mayor el carácter de la producción. Las necesidades básicas y los ritmos de la vida familiar campesina y los de la producción agrícola se mezclan íntimamente y son mutuamente determinantes". Véase: Shanin, Naturaleza y lógica de la economía campesina, 17.

${ }^{40}$ ACC, Fondo Notarial, Notaría Única de Puerto Tejada, t. 2, 1920, fols. 216v-218v. 
acercarnos a una con cierto criterio de fidelidad, es a través de los testimonios directos de las personas que de alguna u otra manera pertenecieron a este universo. El afecto, el recuerdo y la añoranza complementan la información que cualquier escritura puede brindar. En este sentido, Maura Elisa Díaz recordaba:

Nosotros vivíamos en Villarrica, después de ahí nos fuimos a vivir a una parcela en Quintero [década del 40], allí tuvimos ganadería, bestias, caballos, tuvimos animales de corral, patos, cerdos, bimbos, pavos, de todo teníamos allí (...) "Allá [en la finca] teníamos una casa grandota, hecha de bahareque, de ladrillo y guadua embutida y el techo era de teja” (...) "En la finca había un solar, y era grande, y allí había toda clase de fruta. Teníamos sembrado piña, pomarrosa, había anón, chirimoya, caimo, naranjas, había aguacate, sembrábamos yuca, para la casa, maíz, había café, lo cogíamos, para tostar, para la casa, para ayudar con el gasto, teníamos patata, teníamos camote sembrado, caña común $(. .)^{41}$.

Los archivos notariales muestran, específicamente las escrituras que tienen que ver con compraventa de predios, arrendamientos y testamentos, que tendía a ser de linderos estrechos. Tenía un rango de superficie que iba desde $1 / 2$ plaza $^{42}$ (0,32 ha) hasta 10-12 (6,4-7,7 ha), delimitadas generalmente por cultivos de piñuelo o "matarratón", a diferencia de las propiedades más grandes (de más de 10 plazas), que usaban cercos metálicos bien definidos (alambres de púa) ${ }^{43}$. El cerco en piñuelo o "mararratón”, presente en ambos tipos de unidades, era más bien simbólico o referencial (el mismo hecho de que el agricultor escogiera pequeños árboles frutales como el piñuelo o cultivos de leguminosas como el "matarratón” en vez de arbustos densos y espinosos, confirma esta hipótesis), ya que no tendría mucho sentido en una sociedad con un ethos campesino colaboracionista cercar para alejar.

Las fincas más pequeñas (de entre $1 / 2$ y 5 plazas) estaban formadas por una parcela o "lote de terreno" de producción, en donde comúnmente se cultivaba cacao, café y plátano y rondaba poco ganado - en pocas ocasiones también se cultivaban pastos-; una casa de habitación generalmente pajiza o de guadua y

${ }^{41}$ Díaz, entrevista personal.

${ }^{42}$ Según el Boletín de Agricultura, revista del Ministerio de Industrias, una plaza de tierra equivalía a una fanegada y a su vez ésta a 0,64 hectáreas. Véase: Ministerio de Industrias, Boletín Agrícola 4-5 (1931): 155. Tanto la terminología campesina como las transacciones notariales acudían a este término para describir la superficie de un predio, terreno o finca. Lo usaré de aquí en adelante.

${ }^{43}$ ACC, Fondo Notarial, Notaría Única de Puerto Tejada, t. 1, 1932, fols. 64-67. 
techada con los mismos elementos, donde vivían los miembros de la familia; una huerta grande adyacente a la casa, en donde se cultivaban árboles frutales, leguminosas y tubérculos, y se criban animales pequeños, como cerdos y gallinas, como veíamos en entrevistas líneas arriba y en el protocolo notarial anteriormente citado. Había entonces dos espacios de cultivos diferenciados según su función económica: el de la huerta, concebido para el consumo directo de la familia y el de plantación, destinado para producir los cultivos comercializables. En el caso de las unidades menos pequeñas (de entre 5 y 10 plazas), la casa de habitación era más sofisticada, generalmente levantada en barro o ladrillo y cubiertas con tejas de los mismos elementos. Su huerta parecía tener una mayor extensión así como la parcela de plantación. Sin embargo, lo que más la diferenciaba de las unidades más pequeñas era que generalmente tenían un terreno ("manga" o potrero) destinado a las labores ganaderas y otras cuantas plazas para cultivar pastos artificiales como pará, guinea y argentina. En el siguiente protocolo (parcial) reconocemos esos elementos:

En la ciudad de Puerto Tejada (...) a los nueve días del mes de agosto de mil novecientos veintitrés (...) comparecieron el señor Arelino Rengifo y la señora Pércides Patiño (...) vecinos de este municipio de Puerto Tejada (...) dijeron: Primero: Que dan en venta y real y perpetua enajenación al señor Pedro Mina (...) una finca de campo, ubicada en el punto denominado Vuelta Larga, en jurisdicción de este municipio de Puerto Tejada, compuesta de un lote de terreno de diez plazas o fanegadas de cabida, cultivado con mil setecientos (1.700) árboles de cacao, una platanera, unos árboles de café, varios árboles frutales, una manga de pasto artificial (pará) y casa de habitación con su correspondiente cocina, finca que se halla convenientemente cercada, la mayor parte de alambre de púas (...) Segundo: Que hacen la venta de la finca expresada, con todas sus anexidades, usos, costumbres, servidumbres y dependencias que les corresponden, sin reservarse ningún derecho, en la cantidad de tres mil setecientos pesos $(\$ 3.700$, oo $)$ oro legal $(\ldots)^{44}$.

Algunas de estas fincas por lo tanto se basaban en una doble producción: la cacaotera, cafetera y platanera y la que tenía que ver con el negocio de mejoras para ganado (pastos artificiales).

${ }^{44}$ ACC, Fondo Notarial, Notaría Única de Puerto Tejada, t. 1, 1923, fols. 64-67. 


\section{Producción cacaotera desde la unidad familiar campesina: una mirada en detalle}

La parcela agrícola de la finca campesina tradicional de Puerto Tejada, se oponía a la huerta, el otro espacio de cultivo, en la medida que estaba destinada casi por completo a que su producto se comercializara. Su tamaño oscilaba entre la media y las 10 plazas, cultivadas principalmente con árboles de cacao y en menor medida de café y plátanos, como venimos mencionado.

Al parecer, la parcela estaba subdividida en dos partes para producir independientemente los cultivos de mayor importancia, viéndome tentado a afirmar que la parte más grande era dedicada al cacao por ser el producto más importante en términos comerciales - a juzgar por la información estadística encontrada en la prensa-; sin embargo, se debe advertir que este indicador puede ser dudoso debido a que los rendimientos también dependían de factores como la calidad del suelo y el clima. Por lo tanto, una pequeña porción de la parcela podía bastar para que el rendimiento de cacao pudiera igualar o exceder comparativamente los rendimientos de café, suponiendo que el cultivo de éste tuviera la cobertura de la mayoría de la tierra.

Se sembraban no más de 400 árboles de cacao por plaza, junto con árboles de plátano que se encontraban entre tres y cinco metros al frente de cada unidad ${ }^{45}$. Junto con los árboles de plátano, los de cachimbo, que daban sombra y evitaban así el exceso de calor, facilitaban el óptimo crecimiento del fruto. Este espacio era llamado cacaotal y constituía quizá el espacio más importante, en términos productivos, de la finca; también se solían agrupar los árboles de plátano en un espacio diferenciado llamado platanera. El tiempo de producción equivalía al de trabajo, ya que la cosecha de cacao era permanente. Sin embargo, había ciclos de cosechas grandes de dos veces por año, que correspondían a los meses

${ }^{45}$ Llegué a esta conclusión después de valorar y comparar los datos ofrecidos por Ángel María Viveros, Daniel Velasco y Antonio Duque Jiménez. El primero mencionaba: "El cacao uno lo podía sembrar, entre uno y otro, a unos tres metros (...) en una plaza uno podía cultivar unas 400 matas de cacao (...) Había que ver esos palos cuando maduraba el cacao (...) eso uno cogía cacao cada quince días (...) era cacao común, después vino el calabacillo y luego el injerto (...) el calabacillo cargaba más". El segundo recordaba que "lo que era plátano y cacao, mi papá les daba cuatro metros de ventaja ante una mata y otra (...) En una plaza se cultivaban 400 matas de plátano y 400 de cacao". Viveros y Velasco, entrevistas personales. Antonio Duque, Agrónomo Nacional, escribía a mediados de la década de 1930: "Debe aprovecharse bien el terreno sembrando los árboles que justamente pueda contener, teniendo en cuenta que la mejor distancia que debe observarse - en una plantación de cacao- es la de cinco metros (5) y que por consiguiente en una fanegada no deben sembrarse sino 300 árboles a lo sumo (...)”. Véase: Norte, 28 de marzo, 1934, 4. 
Procesos y formas de producción campesina en el norte del Departamento del Cauca: agricultores. César Enrique Zape Jordán

de diciembre/enero y julio/agosto/septiembre ${ }^{46}$, de ahí que la información estadística encontrada en la prensa de la época mostrara incrementos en esas fechas (véase tablas 1 y 3 ).

La cosecha era liderada por el pater familias, acompañado de sus hijos, siempre y cuando tuvieran el mínimo de edad y experiencia suficiente. El agricultor llevaba a cabo esta actividad de manera sencilla: con ayuda de un azadón, pala y/o machete, se abría paso hasta llegar a cada árbol, en donde la recolección de la mazorca era tarea sencilla. Eran árboles de tamaño variable que medían entre dos y cinco metros aproximadamente ${ }^{47}$, cargaban un número importante de mazorcas ${ }^{48}$ y tenían una productividad de cerca de un (1) kilo por árbol ${ }^{49}$. Hay que aclarar que la variedad de cacao referida era

${ }^{46}$ Ángel María Viveros, Maura Elisa Díaz y R. Zawadzky, coinciden en afirmar que las cosechas se daban una o dos veces por mes y que las abundantes coincidían con el inicio y la mitad del año: "La cosecha de cacao se daba cada seis meses, dos veces al año, enero y a mitad de año. En enero la cosecha era abundante, iba disminuyendo hasta que otra vez aumentaba a mitad de año (...) los árboles eran tan grandes que uno no los alcanzaba estando de pie", expresaba Viveros. "Cuando era tiempo de cosecha, cada quince días se cogía cacao, porque nosotros cada ocho días íbamos a las fincas a pelar cacao”, manifestaba M. Díaz. Viveros y Díaz, entrevistas personales. “(...) la producción normal de cada árbol hasta 1900 era de un kilogramo de almendras secas en las cosechas grandes de junio y diciembre de cada año (...) El consumo local y los gastos de conservación de las plantaciones los daban las cosechas pequeñas de los diez meses restantes del año, porque el cacao en buenas condiciones de cultivo da fruto casi permanentemente". Zawadzky, R. "Informe del Director de Estadística Nacional presentado a la Asamblea del Departamento" Extractado de: Relator, 8 de noviembre, 1923, 2. Este ciclo se puede corroborar fácilmente atendiendo a las cifras de producción de cacao anuales presentes en las tablas 1 y 3 .

47 Estimado generado a partir de testimonios varios.

${ }^{48}$ Establecer un número aproximado es difícil. Mientras unos entrevistados se movían entre las 60-150 mazorcas, otros aseguraban que cargaban entre 150-300, e incluso más de la última cifra.

${ }^{49}$ Los índices de productividad los obtuve de dos fuentes: Zawadzky, "Informe del Director de Estadística Nacional presentado a la Asamblea del Departamento"; y de: Mariano Lugari, "Informe del ingeniero agrónomo de las Secciones del Norte y Oriente rendido al Gobernador del Departamento”, El Agricultor Caucano 23-26 (junio-septiembre de 1935): 618. Citado por César Augusto Ayala, "Mentalidad, discurso y política en Puerto Tejada durante la primera mitad del siglo XX”, en Puerto Tejada 100 años, ed. Francisco Zuluaga (Cali: Alcaldía Municipal de Puerto Tejada, 1997), 144. Debo precisar que la primera fuente toma los datos de poblaciones cercanas a Puerto Tejada pertenecientes al Valle del Cauca. $\mathrm{Si}$ aceptamos que había uniformidad agrológica, podemos concluir que los rendimientos, en 12 años, permanecieron constantes. 
criollo, introducido en la zona desde tempranas épocas; otras variantes fueron introducidas promediando la década 1930 aparentemente por influencia de las políticas de fomento estatal. Dos fuentes corroboran este cambio técnico: por un lado Ángel María Viveros, quien en palabras ya citadas recordaba que "había que ver esos palos cuando maduraba el cacao (...) eso uno cogía cacao cada quince días (...) era cacao común, después vino el calabacillo y luego el injerto (...) el calabacillo cargaba más"50; por el otro Celso García, ingeniero de la Campaña Nacional de Cacao en 1955, quien mencionaba que

no se sabe con exactitud qué les ocurrió a las plantaciones de Criollo, pero lo cierto es que en la época 1925-1930, su producción desmejoró tan sensiblemente que se recurrió al empleo de nuevos tipos de cacao para remediar la situación. Fue así como a mediados de 1930 se introdujo a esa región el cacao denominado 'Pajarito', mezcla de los subtipos inferiores del tipo Forastero Trinitario, el cual, según el criterio de esa época, era más rústico, resistente a plagas y enfermedades y producía más y más temprano que el tipo local ${ }^{51}$.

La familia se articulaba completamente a la economía del cacao. Además del pater familias, en la cosecha participaban miembros de la comunidad y de la familia en tercer grado de consanguinidad: tíos, primos, sobrinos, etc. Esta actividad también era llevada a cabo por jornaleros pero más bien de manera eventual ${ }^{52}$. Un aspecto de primer orden era que el deber productivo traspasaba las barreras de la finca, ya que a través del cambio de mano y de la minga se garantizaba que miembros de la comunidad (el compadre, la comadre, la familia grande) también participaran ${ }^{53}$. Como estas situaciones representaban parte de un ciclo irrepetible de intercambios simbólicos repercutidos en lo material ${ }^{54}$,

50 Viveros, entrevista personal.

${ }^{51}$ Celso García, "La situación cacaotera en el norte del Cauca”, Cacao en Colombia: Órgano oficial de la Campaña Nacional de Cacao 4 (1955): 1.

52 "Cogiendo cacao se pagaba [a jornaleros] cuando se necesitaba trabajo adicional y las faenas eran duras", recordaba Maura Elisa Díaz. Díaz, entrevista personal.

${ }^{53}$ Aurelio Cabal, un antiguo agricultor local, recordaba: “Tenían tierra por aquí [Puerto Tejada] los familiares, los tíos; entonces uno iba a la finca, miraba, y ayudaba a cultivar los plátanos". Ángel María Viveros también comentaba: "En la finca de mi papá trabajábamos todos los hermanos haciendo las labores de la labranza (...) uno mismo limpiaba (...)”. Aurelio Cabal, entrevista personal, Puerto Tejada 19 de octubre de 2013; Viveros, entrevista personal.

${ }^{54}$ Los intercambios simbólicos han sido estudiados por Pierre Bourdieu en gran parte de su obra. Para este trabajo revisé el caso práctico que él abordó a mediados de la década de 
Procesos y formas de producción campesina en el norte del Departamento del Cauca: agricultores. César Enrique Zape Jordán

los miembros de la unidad familiar también tenían la obligación moral de devolver el gesto en forma de agradecimiento y bajo un marco colaboracionista, componente fundamental del ethos campesino nortecaucano ${ }^{55}$.

Continuando con la actividad productiva, la familia procedía a realizar las labores de extracción de los frutos desde el interior de las mazorcas. Era un trabajo en grupo, en donde participaban activamente mujeres (incluida la mater familias) y hombres, en especial hijos e hijas ${ }^{56}$ (véase imagen 3). El procedimiento consistía en un proceso de transformación vegetal simple: se abría la corteza por la mitad mediante un corte transversal y se preparaban los frutos, una vez sacados de la mazorca, en un recipiente especial. Allí se dejaban en su jugo unos días mientras ocurría un proceso de absorción. Una vez pasaba esto, se sacaban del recipiente y se disponían en espacios que permitieran

1960 en la región de la Cabilia en el noreste argelino. Es en el estudio de la ética del honor en la sociedad Cabil que Bourdieu, de manera práctica, explica el sentido, producción y reproducción de los intercambios simbólicos. Para revisar sus presupuestos véase: Bourdieu, Bosquejo de una teoría de la práctica, 13-14, 27, 41.

55 Laminga suponía una serie de prácticas ancestrales basadas en unos principios de reciprocidad social y económica, propia de las comunidades campesinas afrocaucanas. Además era el vehículo sobre el que se realizaban los intercambios entre compadres y comadres, ya que abría la posibilidad de retribución material y simbólica. Era, asimismo, una oportunidad para el agradecimiento a través del esparcimiento, el baile y la bebida y por lo tanto funcionaba también como institución cuya función pasaba por asegurar la producción y reproducción social, económica y cultural de las comunidades. Desde un punto de vista más económico/material, no podemos pasar por alto el hecho de que a través de laminga,las formas de producción agrícolas y pecuarias entraban en circuitos mercantiles externos a la comunidad -como parte del intercambio en los mercados urbanos-, debido a los compromisos simbólicos de protección y bienestar que funcionaba a través de la familia grande y el compadrazgo, en los que una mala cosecha, por ejemplo, no suponía la ruina económica y al mismo tiempo empezaba el infinito juego de los intercambios simbólicos. Un anciano habitante de Puerto Tejada recordaba, a propósito: "El cambio de mano era que usted venía hoy a trabajare a mí y entonces yo tenía el deber de ir a devolver el día que me trabajaba, en el trabajo suyo". Véase: Entrevista con un anciano habitante de Puerto Tejada citada por: Mina, Esclavitud y libertad en el valle geográfico del río Cauca, 87. Era este deber moral el que constituía la base del intercambio y así sucesivamente. Los énfasis son míos.

${ }^{56}$ Mencionaba Maura Elisa Díaz: “(...) los miércoles y los sábados nos llevaban a desgranar el cacao, toda la muchachada; nos llevaban a todas seis [hermanas] (...) pero a nosotras nos daban la pasilla [fruto a medio dañar] del cacao (...) Nosotros a la finca nos llevaban era a cosechar, pero a sembrar no, porque en realidad nosotros no vivimos a pie de finca, vivimos al pie de un llano (...) A Quintero nos llevaban como trabajadoras a pelar el cacao, nosotras éramos las que lo desgranábamos”. 
la entrada de calor y luz con el fin de secarlo (las calles de la cabecera eran comúnmente usadas para este fin) ${ }^{57}$. Finalmente, los granos quedaban listos para el consumo y la venta, no sin antes almacenarse en costales de cabuya de 6 arrobas de capacidad $(75 \text { kilos })^{58}$ para ser llevados a las plazas de mercado local o a Puerto Mallarino ${ }^{59}$.

Este proceso técnico daba cuenta de todo un saber campesino ancestral de producción agrícola no solamente en el marco de la familia sino también del mercado. A través de este cúmulo de conocimientos, Puerto Tejada logró transitar los caminos de la modernización nacional. A manera de síntesis, Maura Elisa Díaz describía específicamente el proceso de preparación del grano:

Cuando era tiempo de cosecha, cada quince días se cogía cacao, porque nosotros cada ocho días íbamos a las fincas a pelar cacao (...) y entre la semana cogían las viejas y los dejaban en el picadero (...) luego de haber recogido cacao toda la semana, se picaba el día sábado (...) yo recuerdo tanto que nos tocaba por la noche dejar en la sala y en los corredores de esa casa de aquí de Puerto Tejada, corredores que eran anchos, allí teníamos que dejar ese cacao extendido porque ese cacao cuando había lluvia se ponía negro, se dañaba, entonces había que dejarlo extendido para que secara (...) la mazorca de cacao se abre, se echaban en unas canoas grandes que tenían los viejos, entonces unas daban más agüita que otras, luego se dejaban curar en su misma agua tres días para que cogiera la savia, la baba

57 Daniel Velasco y Ángel Viveros concordaban en mencionar respectivamente: "Tal era la cantidad de cacao que se vendía, no solamente mi papá, porque esto aquí era un cúmulo de agricultores, como sería que se escaseaba la plata y tenían que inmediatamente llamar a Cali para que mandaran plata para poder comprar toda la cosecha (...) las calles estaban pavimentadas de cacao allí secando”; "Usted salía aquí y volteaba a ver ahí y estaba el tendal de café y cacao secándose (...) Esto en los años 40 aproximadamente”. Velasco y Viveros, entrevistas personales.

${ }^{58}$ Luis Emir Ambuila y Rosember Mina, entrevistas personales, Puerto Tejada enero de 2014.

59 Pude obtener información de precios de mercado solo para unos pocos años. Así, para noviembre de 1923, según precio del comerciante Mario Botero, la arroba se pagaba a $\$ 6,40$ (Relator, 5 de noviembre, 1923, 2). Para el $1^{\circ}$ de junio de 1931 se pagaba a un promedio de $\$ 6,00$ (Relator, 1 de junio, 1931, 2); el 1o de diciembre del mismo año a un promedio de $\$ 4,30$ (Relator, 1 de diciembre, 1931,2 ); el $1^{\circ}$ de marzo de 1932 se pagaba a un promedio de $\$ 5,00$ (Relator, 1 de marzo, 1932, 2); el 3 de enero de 1935 se pagaba a un promedio de $\$ 6,20$ (Relator, 3 de enero, 1935, 2). 
Procesos y formas de producción campesina en el norte del Departamento del Cauca: agricultores. César Enrique Zape Jordán

que votaba, y se ponía a secar a los tres días, el grano crecía y además se chupaba toda la vitamina, por eso era el mejor cacao del mundo ${ }^{60}$.

Este mismo procedimiento está representado en las dos fotografías contenidas en la Figura 3, las cuales se exponen a continuación.

Figura 3. Agricultor frente a un árbol de cacao y familia campesina descascarando las mazorcas
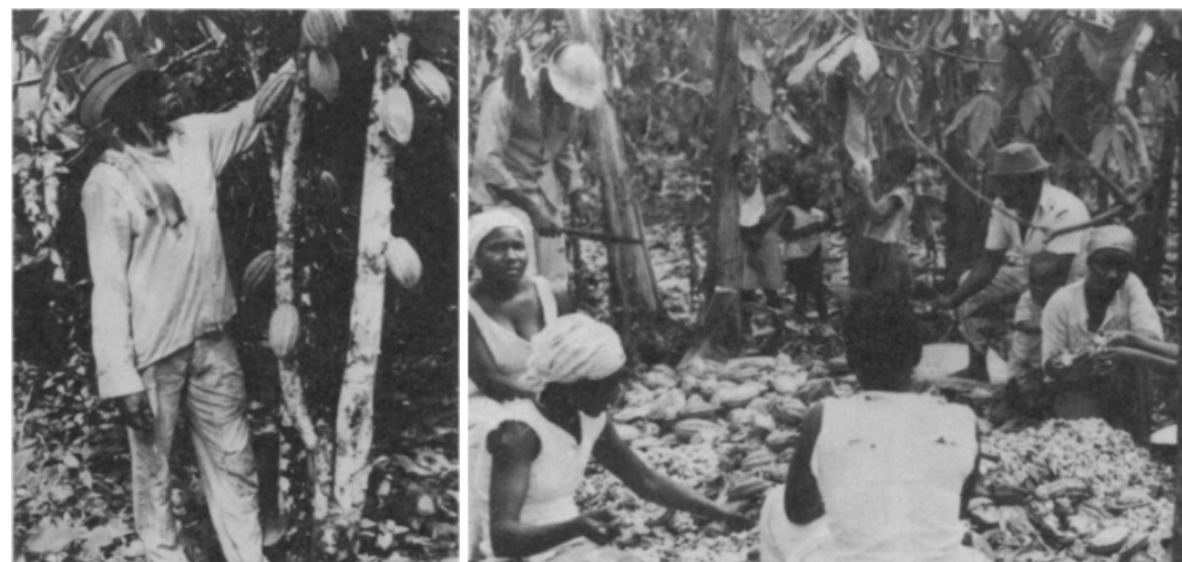

Fuente: Fotos tomadas por Anna Rubbo y Michael Taussig. Fuente: Taussig, M., “Peasant Economics and the Development of Capitalist Agriculture in the Cauca Valley, Colombia”, Latin American Perspectives, 73 (1978).

Estas dos fotografías fueron registradas en la primera mitad de la década de 1970. La imagen de la izquierda muestra a un agricultor observando un árbol de cacao, en el cual se cuentan unas nueve mazorcas en proceso de maduración. El hombre además está rodeado de abundante vegetación, lo que sugiere que se encontraba en una finca tradicional nortecaucana; además viste sombrero y ropas claras, tal como se ven los campesinos de las imágenes 1 y 2. En la imagen de la derecha sobresalen cuatro mujeres y un hombre descascarando las

${ }^{60}$ Díaz, entrevista personal. Con respecto a la calidad del grano, Relator publicó en 1931, bajo el título "El cacao de Puerto Tejada considerado el mejor", el siguiente comunicado: "Guayaquil, 6. Parece que se enviará un agrónomo a Puerto Tejada, población del Departamento del Valle, Colombia, para que traiga una gran cantidad de semillas del mejor cacao del mundo que se produce en dicha región para adaptarlo a las zonas del litoral ecuatoriano. Créese que será esta la mejor medida, pues hará resurgir notablemente la industria ecuatoriana, que ha caído en decadencia, debido al terrible azote de la peste llamada 'Escoba de la Bruja, que está agostando las grandes plantaciones de la costa. El viaje del agrónomo será pronto. La selección del cacao caucano de Puerto Tejada, está acreditada entre los técnicos de este país, como una de las mejores del mundo”. Véase: Relator, 6 de enero, 1931, 1. 
mazorcas de cacao recién arrancadas de los árboles, proceso vegetal simple pero fundamental para la economía campesina de Puerto Tejada y el norte del Cauca a lo largo del siglo XX. Se reconocen además un grupo de niños y, al fondo, otro hombre con machete en mano frente a una platanera, los cuales, junto con las personas ya referidas, hacían parte de una misma familia. Este hecho, así como la presencia de la platanera y la abundante vegetación indican, por un lado, el carácter familiar de las formas de producción cacaotera y, por otro, algunas características físicas de la finca campesina afronortecaucana. A pesar de que las fotografías fueron tomadas en la década de 1970, representan de manera fiel la realidad campesina de las primeras décadas del siglo XX, ya que tanto las prácticas como las técnicas (e incluso aspectos estéticos) se mantuvieron más o menos constantes hasta la segunda mitad del siglo.

Así pues, las anteriores actividades constituían el ciclo básico de la producción campesina de cacao en el norte del Cauca y específicamente en Puerto Tejada. Cabe resaltar que tanto la reproducción de las prácticas agrícolas como el uso de las técnicas de cultivo, cosecha y embalaje, eran aspectos sumamente sencillos que se basaban en la trasmisión de saberes por generaciones así como en una serie de principios que constituían marcos colaboracionistas o, si se quiere, un tipo de racionalidad que definía parte del ethos campesino afronortecaucano.

El carácter comunitario y familiar de la producción agraria garantizaba la supervivencia, reproducción y bienestar de todos los sujetos adscritos al territorio. La finca entonces era un espacio de significación-producción económica donde el agricultor proyectaba los elementos más importantes de su vida, desde las más básicas necesidades biológicas hasta lo más complejos intereses culturales, sociales, económicos y comunitarios; aspectos fundamentales sobre el que se basó el proceso productivo del cacao en el norte el Cauca, de gran importancia en la zona comercial caleña en las primeras décadas del siglo XX y en la economía nacional. El resultado de este proceso figuraba plasmado en las páginas de Norte, el cual mostraba (Figura 4) las cifras de producción con orgullo, en los días de 1934: 
Procesos y formas de producción campesina en el norte del Departamento del Cauca: agricultores. César Enrique Zape Jordán

Figura 4. Producción total de cacao para el año $1933^{61}$

\begin{tabular}{|l|l|l|}
\hline \multicolumn{1}{|c|}{ Meses } & \multicolumn{1}{|c|}{ Bultos } & \multicolumn{1}{c|}{ Arrobas } \\
\hline Enero & 3.135 & 18.810 \\
\hline Febrero & 1.182 & 11.292 \\
\hline Marzo & 674 & 4.044 \\
\hline Abril & 1.364 & 8.184 \\
\hline Mayo & 1.760 & 10.560 \\
\hline Junio & 2.790 & 16.740 \\
Julio & 4.811 & 28.866 \\
Agosto & 3.502 & 21.012 \\
Septiembre & 2.818 & 16.908 \\
\hline Octubre & 987 & 5.922 \\
\hline Noviembre & 1.115 & 6.690 \\
\hline Diciembre & 2.302 & 13.812 \\
\hline Total & 26.440 & 162.840 \\
\hline
\end{tabular}

Fuente: Norte, 25 de abril, 1934, 2.

Gracias a esta producción, Puerto Tejada estaba articulándose en el mercado regional, ofertando hacia la dinámica capital del Valle del Cauca alimentos y materias primas. Insisto, por lo tanto, en que este proceso de producción agrícola fue la base de una economía campesina local que a su vez generó las condiciones para la inserción de Puerto Tejada en el proyecto de modernización nacional.

${ }^{61}$ Datos sobre el cacao emanados de la Oficina de Estadística Municipal, en abril de 1934, a razón de un error estadístico contenido en un informe emitido por el Jefe de Estadística Departamental, denominado "Industria del Cacao", en el que hay inconsistencias en cuanto a la población productora, el número de árboles y la cantidad producida. Dice el comunicado: "El principal productor de este grano en el departamento y en todo el país es el municipio de Puerto Tejada. En el distrito de Puerto Tejada, en el año de 1933, hubo una producción que ascendió a 26.440 bultos o sean (sic) 162.840 arrobas". 
Unos años antes, en 1922, 1923 y 1925, ya entraban y salían de Puerto Mallarino vapores con importantes cantidades de bultos de cacao todos los meses. Sin lugar a dudas, gran parte - sino toda- provenían de las fincas tradicionales portejadeñas. Las Figuras 5 y 6 muestran algunos números que prueban dicho movimiento:

Figura 5. Movimiento fluvial de bultos de cacao en los años 1922, 1923 y 1925

\begin{tabular}{|l|l|l|}
\hline \multicolumn{1}{|c|}{ Años } & \multicolumn{1}{|c|}{$\begin{array}{c}\text { Cantidad de bultos de cacao de } \\
\text { entrada }\end{array}$} & \multicolumn{1}{c|}{$\begin{array}{c}\text { Cantidad de bultos de cacao de } \\
\text { salida }\end{array}$} \\
\hline 1922 & 31.225 & 39 \\
\hline 1923 & 19.137 & 5.377 \\
\hline 1925 & 54 & 29.743 \\
\hline
\end{tabular}

Fuente: Boletín de Estadística Municipal, Cali, tomos de los años 1922, 1923 y 1925.

Figura 6. Movimiento fluvial de bultos de cacao por meses en el año 1925

\begin{tabular}{|l|l|l|}
\hline \multicolumn{1}{|c|}{ Meses } & \multicolumn{1}{|c|}{$\begin{array}{c}\text { Cantidad de bultos de cacao de } \\
\text { entrada }\end{array}$} & \multicolumn{1}{c|}{ Cantidad de bultos de cacao de } \\
salida
\end{tabular}

Fuente: Boletín de Estadística Municipal, Cali, tomo del año 1925. 
Por último, para febrero de 1934 mostraba Saulo Ramírez, entonces Jefe de Estadística Municipal, cifras relacionadas con el movimiento comercial de productos agrícolas (cacao y café) y demás aspectos de la economía municipal, evidenciando parte de la magnitud de la producción agrícola, del destino de los granos y por lo tanto de la importante relación comercial entre Puerto Tejada y Cali. Al respecto precisaba el funcionario:

Informe del Jefe de Estadística Municipal, al Concejo sobre las labores de la oficina a su cargo. Jefe, Saulo Ramírez. Durante el mes de febrero de 1934. Movimiento de granos: Fueron despachados para Cali y otras plazas por las distintas agencias de compras de la ciudad, 1.859 bultos de cacao con 11.154 arrobas que al precio fluctuado entre $\$ 7,00$ y $\$ 7,50$ la arroba, valieron $\$ 81.054,80$; y 596 bultos de café con 3.576 arrobas que al precio de $\$ 3,00$ valieron $\$ 10.728,00^{62}$.

\section{Formas de propiedad y relaciones sociales}

La relación del campesino local con la tierra en cuanto a su propiedad, era peculiar y compleja. En primer lugar porque las fincas campesinas estaban cautivas en grandes propiedades, haciendas, para ser más precisos (como se leen en los protocolos notariales trabajados hasta el momento); en segundo lugar porque estas propiedades estaban poseídas material y efectivamente por un hacendado; en tercer lugar, así la propiedad tuviera poseedor, el campesino tenía autonomía tanto para comercializar sus productos como para vender la unidad sobre la que trabajaba, siempre y cuando pagara por ella al hacendado un canon anual en metálico mediante un contrato de terraje ${ }^{63}$ y el comprador (llegado el caso) se comprometiera, a través de la notaría, a seguir pagando dicho terraje $^{64}$. Información notarial respalda esta última afirmación:

En la población de Puerto Tejada (...) a los diez y siete días del mes de mayo de mil novecientos veinte (...) compareció el señor José María Cantillo (...) dijo, Primero: Que da en venta real y enajenación perpetua a los señores Florentino Montenegro, Antonina Montenegro y Petronila Montenegro (...) vecinos todos del Distrito de Caloto (...) una finca agrícola compuesta de trescientos árboles de cacao cargadores y una platanera, sitos en el punto denominado "Los Bancos", en terrenos de los señores Caicedos

${ }^{62}$ Norte, 6 de abril, 1934, 3.

63 Viveros, entrevista personal.

64 "Lo que diera la tierra uno era libre para venderlo donde fuera, había que pagar, eso sí, el terraje”, relataba Ángel María Viveros. Viveros, entrevista personal. 
Albanes (...) Sexto: que es condición de los compradores seguir pagando a los dueños del terreno los derechos que se cobren por terrajes de esta fecha en adelante $(. . .)^{65}$.

El agricultor era entonces un extraño "propietario". Lo era simbólica y comunitariamente, sin embargo en términos materiales no, o lo era parcialmente. He decidido establecer entonces que su relación era de semipropiedad o de propiedad condicionada. El total de los tipos de transacciones analizados para este trabajo-compraventa de predios rurales, testamentos, arrendamientos y compraventa de mejoras-comprueban este argumento ya que casi siempre se describía el bien involucrado (finca, terreno o mejora) tomando como referencia sus linderos, pero sobre todo el terreno en el que estaba comprendido ${ }^{66}$.

El contrato de terraje, que legitimaba el tipo de propiedad al cual hago referencia, seguía conservando su tradicional terminología, sin embargo ya no parecía responder a la relación de servidumbre colonial. Continuaba siendo un mecanismo de explotación del hombre por el hombre basado en la renta, empero ahora la transacción era cubierta en dinero que, dicho sea de paso, era producido por la economía del cacao. Un aspecto sí se mantenía constante: la renta continuaba siendo usufructuada por el hacendado. Una conclusión importante fue entonces que, para las primeras décadas del siglo XX (entre 1920 y 1934), la relación del agricultor con la propiedad estaba basada en una nueva versión del terraje republicano pero ahora bajo lógicas mercantilistas evidentes. De igual manera, la relaciones sociales parecían definirse en el mismo sentido: el agricultor parecía ajustarse al trabajo como una especie de proletario rural mientras que el gran propietario acumulaba capitales, además de la renta, a través de la venta de productos agrícolas y ganado.

Las prácticas testamentarias plasmadas en los protocolos demuestran que también había campesinos que ejercían propiedad efectiva sobre sus fincas. Sin embargo, este tipo documental no da cuenta del fenómeno completamente, ya que no todas las personas pasaban por las instancias notariales. Si por una parte había campesinos poseedores de fincas por tradición o costumbre, por otra había descendientes de los mismos con derechos por herencias que en muchos casos no formalizaban sus predios. El proceso que provocó el acceso de los derechos de posesión por costumbre o tradición no es fácil de reconstruir y ni siquiera se sabe con certeza cómo fue; lo único que parece seguro es que los

\footnotetext{
${ }^{65}$ ACC, Fondo Notarial, Notaría Única de Puerto Tejada, t. 1, 1920, fols. 197v-200v.

${ }^{66}$ ACC, Fondo Notarial, Notaría Única de Puerto Tejada, t. 1920, 1923, 1925, 1930, 1934.
} 
Procesos y formas de producción campesina en el norte del Departamento del Cauca: agricultores. César Enrique Zape Jordán

campesinos fueron adquiriendo el derecho efectivo sobre sus fincas en épocas en que la esclavitud continuaba siendo legal, y tras un imparable proceso de construcción y consolidación de la familia extensa y el territorio.

La explotación agrícola y por lo tanto la producción de cacao también revestía otra forma. Esta se basaba en el arrendamiento de pequeños terrenos o de fincas enteras por parte de campesinos y herederos de bienes agrícolas que habían logrado extender sus propiedades o simplemente vivir de la renta. Este tipo de arrendamiento se formalizaba por escritura notarial y por lo general las partes acordaban de común acuerdo establecerlo por un periodo determinado. Casi siempre se arrendaban fincas pequeñas (de entre 3 y 10 plazas) y medianas (de 10 plazas en adelante), del mismo tipo de unidad caracterizado líneas arriba, cuyo plusvalor se determinaba por la renta sobre la tierra -al igual que el terraje-, con lo cual el agricultor (sin tierra) se veía obligado, en virtud del contrato, a pagar un canon que se estipulaba generalmente cada año. El agricultor-arrendatario tenía plena autonomía para modificar la unidad y comercializar los cultivos que produjera sobre ésta, de hecho, el propietario/ arrendador incluía en el protocolo notarial los precios de compra por cultivos producidos, de manera que ofrecía un precio, por ejemplo, por cada árbol de cacao listo para producir; y otro -inferior-por cada árbol joven (o sin cargar). En la siguiente escritura está plasmada la formalización de esta práctica:

En la población de Puerto Tejada (...) a los veinticuatro días del mes de junio de mil novecientos veinte (...) comparecieron la señora Agripina Castro viuda de Larrahondo y Juan de la Cruz Segura (...) Primero: que da en arrendamiento al señor Segura, por el término de cinco (5) años, contados desde el día primero de marzo del año en curso en adelante, una finca rural compuesta de diez plazas de terreno, cultivadas en parte con cacao, café, plátano, casa de habitación, construida de guadua, y el resto en rastrojo (...) Segundo: Que el valor del arrendamiento de la expresada finca es el de trescientos pesos $(\$ 300$, oo $)$ oro legal un año y los otros cuatro a razón de cuatrocientos pesos, anticipados, los cuales declara la arrendadora tener recibidos a su satisfacción; el segundo año de trescientos pesos (...) y los otros tres años, por trimestres vencidos de a cien pesos $(\$ 100)(\ldots)$ Tercero: Que reconocerá al arrendatario Segura las siguientes mejoras: los árboles de cacao que siembre y entregue de tres a cuatro años de edad y a una distancia mínima de cuatro metros de distancia el uno del otro, a razón de veinticinco centavos oro cada árbol, siembra que se concretará a llenar los vacíos que hayan en la parte actualmente cultivada con el mismo cultivo; plaza de pasto (pará) que siembre y entregue en estado de servicio, a razón de doce pesos $(\$ 12,00)$ oro, cada plaza; y que las mejoras que tiene 
en la casa de habitación y las reparaciones de las correspondientes cercas, serán avaluadas de común acuerdo entre los contratantes (...) Quinto: Que la citada finca la adquirió la arrendadora Castro viuda de Larrahondo, por herencia de su legítimo esposo señor Manuel Larrahondo $(. . .)^{67}$.

Absolutamente todos los protocolos revisados sacaban a relucir la posesión de árboles de cacao en el momento de referirse a la composición de las unidades, mejoras o terrenos, lo que quería decir que era el producto más valioso - quizá después de la casa de habitación- de las propiedades. Nótese que la primera mejora referida en la anterior escritura tenía que ver con árboles de cacao.

\section{Conclusiones}

Sostengo que la base sobre la que Puerto Tejada creció materialmente tuvo que ver con una producción afrocampesina basada en el cultivo y producción de cacao en las primeras décadas del siglo XX. El vertiginoso incremento tanto de su producción como de su comercio, estuvo estrechamente ligado con un proyecto capitalista de modernización a nivel mundial y latinoamericano. El puente fue Cali, capital del Departamento del Valle del Cauca y población más importante de la región, ciudad que para esos años estaba creciendo comercial, industrial y demográficamente. El nexo con este mercado fue la clav e para que se articularan producción campesina afronortecaucana y consumo caleño a través de un grupo cada vez más numeroso de intermediarios. Esa producción que, dicho sea de paso, era familiar y llevada a cabo mediante faenas comunitarias/familiares con técnicas y herramientas simples, aprendidas durante generaciones.

El tipo de campesino presente en Puerto Tejada a principios del siglo $\mathrm{XX}$ estaba dedicado más que a las labores pecuarias, a las agrícolas. Una vez revisadas y analizadas las fuentes, sobre todo las orales, resolví llamarlo agricultor. Este agricultor era en esencia cultivador de pan-coger en especial de cacao, producto que sumado al café y al plátano, lograron coadyuvar al bienestar de la familia, el pago de la propiedad, la compra de insumos y al esparcimiento. Pertenecía a una comunidad que mantenía una serie de códigos morales basados en una ética de la reciprocidad. Dicha comunidad se basaba en la familia grande, y era sobre la cual se desplegaban principios o valores, reproducidos bajo instituciones como la minga y el cambio de mano.

${ }^{67}$ ACC, Fondo Notarial, Notaría Única de Puerto Tejada, t. 2, 1920, fols. 261-263 
Para el campesino-agricultor que estaba produciendo bajo terraje, su relación con la propiedad era peculiar. Aunque podía vender su finca y lo producido en ella, se encontraba insertada en otra propiedad (debido al proceso histórico de poblamiento y esclavización, como ya dijimos), además continuaba pagando el canon anual en metálico. Muchas veces la deuda pasaba a personas que compraban dicho predio. En fin, no era un derecho de posesión definitivo o, lo que es lo mismo, su propiedad no era efectiva. Los campesinosagricultores heredaron un territorio previamente construido y significado por sus antepasados. Sobre éste no solamente produjeron y reprodujeron realidades simbólicas, sino que además lograron gestionar actividades productivas comunitarias que terminaron formando economías campesinas propias.

La ética campesina afronortecaucana suponía un bloqueo ante la avanzada capitalista, ya que la relación tierra-mercantilización estaba fuera de discusión. Así mismo, la existencia de balseros campesinos o "bajadores" revela esta incompatibilidad. Sin embargo, esto no fue absoluto. Según los protocolos notariales, ya se venían presentando prácticas mercantiles tanto con cultivos como con unidades de producción. Así lo muestran también las prácticas de arrendamiento entre campesinos. Estábamos entonces asistiendo a un proceso de conflictividad de éticas o racionalidades, en las que las prácticas de mercantilización de los factores estaban tomando fuerza.

\section{Referencias bibliográficas}

\section{Fuentes primarias}

\section{Manuscritas}

\section{Protocolos Notariales}

Centro de Investigaciones Históricas José María Arboleda Llorente - Archivo Central del Cauca - Universidad del Cauca, Fondo Notarial, Notaría Única de Puerto Tejada, t. 1920, 1923, 1925, 1930, 1934.

\section{Impresas}

\section{Prensa}

Boletín de Estadística Municipal, Cali, tomos de los años 1922, 1923 y 1925.

El Día, Cali, n. 409.

Norte, Puerto Tejada, nos. 7, 8, 10.

Relator, Cali, nos. 1934, 1937, 4140, 4188, 4264, 4423, 4498, 5394. 


\section{Informes y estudios}

Departamento de Administración Nacional de Estadística. «Perfil demográfico de Puerto Tejada - Censo 2005.» DANE. 2 de Septiembre de 2015. www.dane.gov. co/files/censo2005/PERFIL_PDF_CG2005/19573T7T000.PD.

García, Celso. «La situación cacaotera en el norte del Cauca.» Cacao en Colombia: Órgano oficial de la Campaña Nacional de Cacao, 1955.

Ministerio de Industrias. «Boletín Agrícola.» Boletín Agrícola, 1931.

\section{Testimonios orales}

Las personas que aportaron de cara al proceso de conversación fueron: Ángel María Viveros, de 101 años, antiguo agricultor y de padres campesinos; Daniel Velasco, de 84 años, agricultor toda su vida y de padres campesinos; Maura Elisa Díaz, de 76 años, profesora jubilada y de padres campesinos; Eddie Azcárate, de 80 años, antiguo funcionario público; Aurelio Cabal, de 71 años, agricultor "retirado", de padres vinculados al campo; Luis Emir Ambuila, de 50 años, actual agricultor de ascendencia campesina; y Rosember Mina, de 50 años, vinculado actualmente al sector rural, de padres campesinos.

\section{Material fotográfico}

Archivos fotográficos personales de Isabel Ararat, habitante del municipio de Puerto Tejada.

Página web del Banco de la República: http://www.banrepcultural.org/blaavirtual/ publicacionesbanrep/boletin/boleti5/bol21/simmond.htm. También en: http:// bibliotecadigital.icesi.edu.co/biblioteca_digital/handle/10906/56743.

Taussig, M., "Peasant Economics and the Development of Capitalist Agriculture in the Cauca Valley, Colombia”, Latin American Perspectives, 73 (1978).

\section{Fuentes secundarias}

Almario, Óscar. Cali y el Valle del Cauca: configuración moderna y reconfiguración contemporánea de la región y la ciudad-región. Vol. II, de Historia de Cali, siglo XX. Política, de Esteban Morera, 70-93. Cali: Programa Editorial Facultad de Humanidades, Universidad del Valle, 2012.

Aprile, Jacques. Los pueblos negros caucanos y la fundación de Puerto Tejada. Cali: Gerencia para el Desarrollo Cultural - Gobernación del Valle del Cauca, 1994.

Ayala Diago, César Augusto. «Mentalidad, discurso y política en Puerto Tejada durante la primera mitad del siglo XX.» En Puerto Tejada 100 años, de Francisco Zuluaga, 107-146. Cali: Alcaldía Municipal de Puerto Tejada, 1997.

Bonnemaison, Joël. La géographie culturelle. Paris: Comité des travaux historiques et scientifiques, 2000.

Bourdieu, Pierre. Bosquejo de una teoría de la práctica. Buenos Aires: Prometeo Libros, 2012.

Bourdieu, Pierre, y Terry Eagleton. «Doxa y vida cotidiana: una entrevista.» En Ideología: un mapa de la cuestión, de Slavoj Žižek, 295-308. Buenos Aires: Fondo de Cultura Económica, 2003. 
Procesos y formas de producción campesina en el norte del Departamento del Cauca: agricultores. César Enrique Zape Jordán

Breton, Víctor. «¿De campesino a agricultor? La pequeña producción familiar en el marco del desarrollo capitalista» En Historia Agraria: revista de agricultura e historia rural 1993: 129-159.

Foucault, Michel. El orden del discurso. Barcelona: Tusquets Editores, 2010.

Haesbaert, Rogério. Territórios Alternativos. São Paulo: Contexto, 2006.

Mejía, Eduardo «Campesinos, poblamiento y conflictos: valle del Cauca 1800-1848.» Informe final de investigación Colciencias, Universidad del Valle, Facultad de Humanidades, Departamento de Historia, 2000.

Mejía, Eduardo. Origen del campesinado vallecaucano: siglo XVIII y siglo XIX. Cali: Editorial Facultad de Humanidades, Universidad del Valle, 1993.

Mina, Mateo. Esclavitud y libertad en el valle del río Cauca. Bogotá: Publicaciones La Rosca, 1975.

Moncayo, Armando y Mejía, Eduardo. «La transición de hacienda a ingenio azucarero industrializado en el valle del río Cauca. 1850-1923.» Tesis de Licenciatura en Historia, División de Humanidades, Universidad del Valle.

Palacios, Marco. ¿De quién es la tierra? Propiedad, politización y protesta campesina en la década de 1930. Bogotá: FCE, Universidad de los Andes, 2011.

Polanyi, Karl. La gran transformación: crítica del liberalismo económico. Madrid: de la Piqueta, 1997.

Polanyi, Karl. «Nuestra obsoleta mentalidad de mercado.»Cuadernos de Economía, 1994: 249-266.

Rodríguez, José Ángel. «El hombre en el espacio.» En Visiones del oficio:Historiadores venezolanos en el siglo XXI, de José Ángel Rodríguez, 35-56. Caracas: Fondo Editorial de Humanidades y Educación - Universidad Central de Venezuela, 2000.

Romero, Mario Diego. «La familia.»Cali, Valle del Cauca: Universidad del Valle, 2013.

Shanin, Teodor. Naturaleza y lógica de la economía campesina. Barcelona: Anagrama, 1976.

Stavrakakis, Yannis. La izquierda lacaniana:psicoanálisis, teoría, política. Buenos Aires: Fondo de Cultura Económica, 2010.

Valdivia, Luis. Economía y Espacio: el valle del Cauca, 1850-1950. Cali: Universidad del Valle, 1992.

Valdivia, Luis. «Origen y situación de la pequeña posesión campesina en el Valle del Cauca, siglo XIX.» Historia y Espacio: Revista de estudios históricos y regionales, 1994: 53-111.

Valencia, Alonso. Estado Soberano del Cauca: Federalismo y Regeneración. Bogotá: Banco de la República, 1988.

Valencia, Alonso. Marginados y "sepultados en los montes": orígenes de la insurgencia social en el valle del río Cauca, 1810-1830. Cali: Programa Editorial Universidad del Valle, 2008.

Zape, César «Producción agrícola en el Norte del Cauca: agricultores del cacao en Puerto Tejada, 1916-1934.» Tesis de Historia, Departamento de Historia, Universidad del Valle, 2014. 